\title{
LÍVIA TRELLOVÁ: CONSTITUTIONAL LAW ASPECTS OF TERRITORIAL SELF-GOVERNMENT
}

Wolters Kluwer, Bratislava, 228 p.

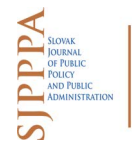

DOI: https://doi.org/10.34135/sjpppa.210810 sjpppa.fsvucm.sk ISSN 1339-7826 (online) c) 2021 The Faculty of Social Sciences University of Ss. Cyril and Methodius. Trmave

Territorial self-government is an area of public administration that is constantly evolving. It is therefore important to learn about new perspectives on this issue. Territorial self-government is part of modern corporate governance, which is based on a plurality of political and social interests. The reason why every citizen should have a basic knowledge of the functioning of territorial self-government is that each of us has the right to participate in its management. The importance of territorial self-government in the system of state management is also confirmed by the fact that it has been granted an important position in the main law of the state - the Constitution of the Slovak Republic. Although this topic is extremely important, it is not given adequate attention at the theoretical, constitutional level. Author JUDr. Lívia Trellová, PhD. in her publication "Constitutional law aspects of territorial self-government" tries to deepen this issue. She emphasizes that the constitutional regulation defines territorial self-government rather in a framework and that the material scope of the municipality's self-government rather leaves the areas of legal regulation. According to the author, since the adoption of the Constitution of the Slovak Republic in 1992, there have naturally been several theoretically unanswered questions in matters of territorial selfgovernment.

The monograph is divided into five chapters, which deal with individual constitutional aspects of territorial self-government. In the introduction to the first chapter, the author tries to theoretically develop the concept of territorial self-government and its expression in the horizontal and vertical power in the state. The relatively little-studied relationship of territorial self-government to the system of division of power is described here quite extensively. In this part, the author also relies on the historical and theoretical development of the idea of territorial self-government through several authors who have dealt with this issue in the past. These are mainly authors such as Karel Klíma, Zdeněk Koudelka and Georg Jellinek. At the end of the first chapter, the author defines the space that describes the origin of the regulation itself in the international and national context. In the second chapter of the presented monograph, we get to the issue of the 
constitutional expression of territorial self-government in the conditions of the Slovak Republic. The author first emphasizes the importance of territorial self-government in the system of democratic organization of society. She writes that the institute of territorial self-government has been experiencing a kind of renaissance since the 19th century. The author continues with the idea that we should perceive self-government not only as a legal concept but also as a socio-cultural or economic concept. The chapter then deals with the theoretical definition of basic concepts that are closely related to this issue. Here, the author relies on several authors to provide the broadest possible picture of the issue of territorial selfgovernment. Among them, we can find several well-known Slovak, Czech or foreign authors. The next part of this chapter briefly deals with the origin of territorial self-government in the Constitution of the Slovak Republic. The chapter continues by defining the basic units of territorial self-government. The author pays attention to a higher territorial unit but pays most attention to the municipality. It defines it, describes the basic features, lists the rights and obligations of the population of the municipality, or points to the fragmentation of municipal self-government, which needs to be addressed through municipal reform. In this part, the author works mainly with legal regulations and analyses various situations through good examples from abroad. The middle part of this chapter deals in more detail with local government bodies, more specifically with municipal bodies in the form of municipal council and mayor. The author broadly defines these terms, describes their activities, competencies, etc. The conclusion of this chapter provides readers with information on direct forms of territorial self-government. The author places particular emphasis on the recognizability of the institute of referendums at the local level. The author also points out its shortcomings, which it tries to analyse and, last but not least, to provide solutions to eliminate them.

The third chapter deals with the constitutional regulation of territorial self-government in the context of the principles of the rule of law. At the beginning of this part, before the analysis of the constitutional regulation of the Slovak Republic, the author considers it necessary to comment on the concepts of constitutional and legal principles. It theoretically defines these concepts and also describes their role in the legal system. In the next part of this chapter, the author deals with the constitutional principles of territorial self-government, where the author relies mainly on the fourth chapter of the Constitution of the Slovak Republic. At the end of this chapter, the author briefly introduces territorial self-government in the context of the material core of the Constitution of the Slovak Republic.

The penultimate chapter of this monograph deals with the right 
to territorial self-government as constitutional law. In the beginning, the author declares that such a right was historically given in the 13th century in the Great Charter of Freedoms (Magna Charta Libertatum). This part of the monograph describes the importance of territorial self-government in the legal system of a democratic state and also the possibility of the state delegating certain powers to self-governments. The author further writes that perceiving the right to self-government is not uniform among different authors. As a starting point for these different opinions, she will use the words of Miloš Matula, who says that the basis of the activities of selfgoverning bodies is the right to self-government, which can be understood in two dimensions. The first dimension represents the citizen's right to self-government and the second dimension is the right of territorial selfgoverning units to self-government. She argues that these dimensions are not entirely interchangeable. The next part of this chapter deals with the content of the right to exercise territorial self-government. These rights are listed in the relevant laws and also in the Constitution of the Slovak Republic. The author again highlights the persistent problem in the administration of small municipalities in Slovakia. She also bases her claims on the words of Jozef Tekeli, who said that our legal system recognizes the institute of compulsory administration, which, however, is closely linked only to economic and financial indicators, and that no valid legislation addresses the possibility of introducing compulsory administration in cases of demonstrable repeated illegal proceedings by municipal authorities, resp. the inability of these bodies to carry out public administration.

The last chapter, and thus the conclusion of the presented monograph, presents the area of legal norm-setting of territorial self-government. This chapter is divided into two subchapters, the first dealing with legal legislation in the field of independent competence and the second part with legal legislation in the field of delegated competence. In the first part, the author writes mainly about the right of municipalities to adopt generally binding regulations. It adds that such regulations may be adopted either for the performance of tasks related to the original jurisdiction or in the case of delegated performance when it is empowered to do so by law. There is therefore a problem here that these concepts are not sufficiently determined in the Constitution of the Slovak Republic and therefore it is not even possible to rely on the current legislation. In the case of legal legislation in the area of delegated competence, the author draws attention to the problem of inconsistency of the legal order. This fact is illustrated in the presented monograph on the example of the disproportionality of the legal conditions of compliance of the regulation in the field of territorial self- 
government with other legal regulations. The conclusion of the publication presents a set of solutions concerning the legislation of municipalities because this area is one of the basic activities of local government.

The presented monograph expands the area of territorial selfgovernment and its legal understanding. This issue is extremely extensive and the knowledge about it is practically inexhaustible. In this publication, the author discusses the constitutional aspects of territorial self-government and outlines several problems, to which she also adds solutions from applied practice. The monograph is suitable for the reader, who already has basic knowledge about the functioning of territorial self-government, as the author deepens this topic more. The monograph could also be suitable as study material for university students focused on constitutional law. It can also serve as material to contribute to professional discussions on this topic.

Erik Urc

Faculty of Social Sciences

University of Ss. Cyril and Methodius in Trnava Department of Public Administration Bučianska 4/A, 91701 Trnava, Slovakia urc.erik@gmail.com 